Atıf Bilgisi: Yıldız, S. (2021). Sağlık iletişimi kampanyalarında sosyal medya reklamları kullanımı: İnme farkındalığı konulu bir örnek olay. INİF E-Dergi, 6(1), 103-122.

\title{
SAĞLIK İLETISSIMİ KAMPANYALARINDA SOSYAL MEDYA REKLAMLARI KULLANIMI: İNME FARKINDALIĞI KONULU BİR ÖRNEK OLAY
}

Dr. Öğr. Üyesi Serdar YILDIZ*

DOI: 10.47107/inifedergi.888544

Araștırma Makalesi $^{* *}$

Başvuru Tarihi: 01.03.2021

Kabul Tarihi: 13.04.2021

$\ddot{\mathbf{O} z}$

Sosyal medya, markaların pazarlama iletişimi çabalarında olduğu gibi, toplumsal fayda amaçlı kampanyalarda da sıklıkla kullanılmaktadır. Sağlık iletişiminde sosyal medyanın kullanımına dair çok sayıda çalışma yapılmış olsa da bu kapsamda reklam uygulamalarına odaklanan çalışmalar oldukça sınırlıdır. Bu çalışmada, Türk Beyin Damar Hastalıkları Derneği tarafından 2020 yılı Ekim ayı itibariyle gerçekleştirilen inme farkındalığı kampanyası örnek olay olarak ele alınmıştır. Öncelikle genel bir perspektifte kampanyanın iletişim stratejisi, mesaj içerikleri ve uygulamaları incelenmiştir. $\mathrm{Bu}$ inceleme kampanyanın, inme farkındalığı kampanyalarından beklenen temel bilgileri geleneksel ve dijital mecralarda stratejik bir bütünlük içerisinde hedef kitleye aktardığını göstermiştir. Ardından sosyal medya reklamlarının yayın performansı; gösterim, erişim, izleme, tıklama gibi metrikler üzerinden analiz edilmiştir. Bu analiz, sosyal medya reklamlarının farkındalık kampanyasına katkılarını ortaya koymuş ve farklı sağlık mesaj içeriklerinin elde ettiği online etkileşim sonuçlarını karşılaştırma olanağı sunmuştur. Araştırma sonuçları, sosyal medya reklamları sayesinde kampanyanın ulaştığı kitlenin ciddi boyutta genişlediğini ve coğrafi olarak çeşitlendiğini ortaya koymuştur. Reklam yayın sürecinde kampanya web sitesine yönlendirilen tüm trafiğin \%75'ten fazlasının sosyal medya reklamlarından kaynaklandığı görülmüştür. Reklamların yayın performansı, reklam hedeflerine uygun olarak gerçekleşmiştir. Aynı hedefle ve hedef kitle tanımıyla yayınlanan iki ayrı video içeriğin elde ettiği online etkileşim sonuçları arasındaki fark ise sağlık iletişiminde kaynak güvenilirliği açısından uzman tanıklığının önemine işaret etmiştir. Sağlık mesajlarını, alan uzmanı bir doktorun aktardığı video, benzer mesajları masaüstü animasyon biçiminde aktaran videoya kıyasla daha yüksek oranda izlenme ve tıklanma performansı ortaya koymuştur. Bu çalışma sonunda, kâr amacı gütmeyen bir kurum tarafından gerçekleştirilmiş olan kampanya örneği üzerinden sağlık iletişiminde sosyal medya reklamlarının kullanımına dair çıkarımlar ve öneriler sunulmuştur.

Anahtar Kelimeler: Să̆lık İletişimi, Sosyal Medya, Reklam, İnme Farkındalı̆̆l, Örnek Olay

\section{THE USE OF SOCIAL MEDIA ADVERTISING IN HEALTH COMMUNICATION CAMPAIGNS: A CASE STUDY ABOUT STROKE AWARENESS}

\begin{abstract}
Social media is frequently used in social campaigns similar to marketing communication efforts of brands. Although there are many studies on the use of social media in health communication, studies focusing on advertising practices in this context are quite limited. This study investigated the stroke awareness campaign carried out by the Turkish Cerebrovascular Diseases Society as of October 2020 as a case study. First of all, the communication strategy, message content, and executions of the campaign were reviewed in general. This review showed that the campaign communicated the essential information expected from stroke awareness campaigns in the integration of traditional and digital media. Then, the performance of the social media ads was analyzed in terms of metrics such as impressions, reach, views, and clicks. This analysis revealed the benefits of social media ads to the awareness campaign and provided the opportunity to compare the online engagement outcomes of different posts. The results revealed that the ads increased the number and geographic diversity of the campaign audience substantially. During the advertising campaign, more than $75 \%$ of all website traffic was based on social media ads. The performances of the ads were in accordance with their advertising objectives. The difference between online engagement results of two video

\footnotetext{
*Anadolu Üniversitesi, İletişim Bilimleri Fakültesi, Halkla İlişkiler ve Reklamcılık Bölümü, E-mail: serdar.y@anadolu.edu.tr, ORCID ID: 0000-0002-1565-3552

** Yazar / yazarlar, makalede araştırma ve yayın etiğine uyulduğuna ve kullanılan fikir ve sanat eserleri için telif hakları düzenlemelerine riayet edildiğine yönelik beyanda bulunmuştur.
} 
ads directed to the same target audience with the same objective pointed out the importance of expert testimony in terms of source credibility in health communication. The video in which a health specialist communicates the messages achieved higher views and click performance compared to the video that conveys similar messages with animation format. The study presented implications and suggestions about the use of social media advertisements in health communication through a campaign case of a non-profit organization.

Keywords: Health Communication, Social Media, Advertising, Stroke Awareness, Case Study

\section{Giriş}

Sosyal medya ve diğer dijital iletişim araçları, ticari amaçlı pazarlama iletişimi faaliyetlerinde olduğu gibi, toplumsal fayda amaçlı uygulamalarda da yaygın olarak kullanılmaktadır. Söz konusu toplumsal amaçlı uygulamalar arasında sağlık iletişimi önemli bir yer tutmaktadır. Gerek sağlık hizmeti sunumu kapsamında gerek farkındalık, bilgilendirme ve davranış değişikliği amaçlı toplum sağlığını geliştirme uygulamalarında sosyal medya ve diğer dijital iletişim olanaklarından yararlanılmaktadır. Bu konularla ilgili olarak; sağlık ve iletişim alanlarında çalışan uygulamacılar ve akademisyenler, hastaneler, ilaç endüstrisi ve diğer sağlık kuruluşlarının yanı sıra kamu ve sivil toplum kuruluşları gibi aktörler iletişim faaliyetleri yürütmekte ya da bunlara katkı sağlamaktadır.

Özel sağlık kuruluşları iletişim araçlarını çoğunlukla reklam ve tanıtım amacıyla kullanırken, kamu kurumları ve kâr amacı gütmeyen kurumların ise sosyal pazarlama anlayışıyla hareket ettikleri söylenebilir (Tosyalı ve Sütçü, 2016). Sosyal pazarlama, sağlık gibi toplumsal konularda farkındalık yaratmak, tutum ve davranışları değiştirmek amacıyla, pazarlama ilkelerini toplumsal fikir ve uygulamaları teşvik etme çabalarına uyarlayan bir disiplin olarak tanımlanabilir (Taubenheim vd., 2012, s. 205). Her ne amaçla olursa olsun, burada sayılan tüm aktörlerin benzer iletişim süreçlerini hayata geçirdikleri ve sosyal medya platformları gibi iletişim araçlarını benzer biçimde kullandıkları söylenebilir.

Sosyal medya platformları bireyleri bir ağ ya da topluluk biçiminde bir araya getiren ve ülkemizde de yaygın olarak kullanılan iletişim araçlarıdır. Bireyler ve gruplar arası iletişime olanak sağladığ gibi kitleleri etkileme potansiyeline de sahip olan bu ortamlar, aynı zamanda önemli birer reklam mecrasıdır. Bu mecralar, işleyiş yapısı gereği kullanıcı verilerini derlemekte ve bunları reklam uygulamalarını daha etkin hale getirmek amacıyla kullanmaktadır. Kullanıcıların diğer çevrimiçi davranışları gibi, reklamlara verdikleri tepkiler de bu kapsamda ölçümlenebilmektedir. Reklamcılık açısından genel bir ifadeyle, kullanıcı hedefleme, belirli hedef kitlelere özel içerikler iletme ve çevrimiçi davranışsal tepkileri gözlemleme olarak özetleyebileceğimiz bu olanaklar, ticari iletişim süreçlerinde olduğu gibi, toplumsal amaçlı uygulamalar için de oldukça değerlidir. $\mathrm{Bu}$ sayede, örnek olarak bir sağlı iletişimi kampanyasında; ilgili risk gruplarını hedefleme, özellikli ve diğer araçlarla ulaşılması zor hedef kitlelere ulaşma, bu kitlelerle etkileşim yaratma, mesajların erişimini, sıklığını ve dolayısıyla etkisini arttırma gibi olanaklardan yararlanılabilir. Daha da önemlisi, bu mecraların genellikle kisitlı kaynaklarla gerçekleştirilen toplumsal fayda amaçlı iletişim uygulamalarında, geleneksel mecralara kıyasla düşük maliyet avantajı sayesinde kaynakların etkin kullanımına ve kolay ölçümlenebilir sonuçlar sayesinde hesap verebilirliğe katkı sağladığı belirtilebilir. Bu noktada, sosyal pazarlama ya da sağlık iletişimi gibi alanlarda söz konusu mecraların nasıl kullanıldığını incelemek, daha etkin biçimde nasıl kullanılabileceğini anlamak adına yararlı olacaktır.

$\mathrm{Bu}$ çalışmada, Türk Beyin Damar Hastalıkları Derneği (TBDHD) tarafından yürütülen inme farkındalığı konulu sağlık iletişimi kampanyası örnek olay olarak ele 
alınmış; bu kampanyada sosyal medya reklam uygulamalarının nasıl kullanıldığı ayrıntılı olarak incelenmiştir. Sağlık iletişiminde sosyal medyanın kullanımına ilişkin çok sayıda çalışma olmasına karşın, bu bağlamda reklam uygulamalarını kapsayan çalışmaların son derece sınırlı olduğu görülmektedir. Sağlık iletişimi ve reklamcılık ilişsisi açısından daha çok kamu spotları özelinde araştırmalar yapılmış olsa da yukarıda değinilen özellikleri açısından sosyal medya reklam uygulamalarını bu çalışmadaki yaklaşıma benzer biçimde inceleyen araştırmalar sınırlıdır. Son derece önemli bir sağlık sorunu olmasına rağmen toplum genelinde, kalp hastalıkları ve kanser gibi daha yaygın olarak bilinen sağlık problemleri kadar dikkat çekmeyen ve hakkında çok az farkındalık çalışması yapılmış olan inme konusunda bir örnek olayı ele alması bu çalışmanın bir diğer önemli özelliğidir. Çalışmada ayrıca, ülkemizde inme konusunda en önemli otoritelerden biri olan TBDHD tarafından uygulanmış olan güncel bir kampanyaya dair saha verilerinin paylaşılmasının gerek reklamcılık gerek sağlık iletişimi alanına katkı sağlayacağı düşünülmektedir.

\section{Sağlık İletişimi ve Farkındalık Çalışmaları}

Sağlık iletişimi, gerek bireylerin sağlık konusuna yönelik artan ilgileri ve kaygıları gerek bu alandaki iletişim olanaklarının çeşitlenmesi gibi nedenlerle her geçen gün gelişmekte ve başlı başına bir disiplin haline gelmektedir. İnsanın olduğu her ortam ve koşulda iletişimin varlığı, insanın varlığını sürdürmesi için ise sağlığın en önemli olgulardan biri olması sağlı iletişimini çok boyutlu ve kapsamlı bir alan haline getirmektedir. Yüksel (2018, s. 16) en genel anlamda sağlık iletişimini "sağlık alanında ihtiyaç duyulan iletişimin tümü" şeklinde tanımlamış; kapsamının ise sağlık hizmeti alan ve veren arasındaki iletişimden, sağlık alanındaki ürün ve hizmetlerin tanıtımına; sağlık konularıyla ilgili farkındalık ve bilinçlendirme çalışmalarından, sağlık okuryazarlığına kadar uzandığını belirtmiştir.

Sağlık iletişiminin, toplumu bilinçlendirme ve farkındalık boyutuna odaklanan bu çalışma kapsamında sağlık iletişimi, "sağlığı geliştirme yaklaşımı ile uyumlu olarak, bireyleri, kurumları ve halkı önemli sağlık sorunları hakkında bilgilendirme, etkileme ve motive etme, sanat ve tekniği" (Avc1 ve Avşar, 2014, s. 182) olarak tanımlanabilir. Sağlık iletişiminin; hastalıkların önlenmesi ile sağlığın ve yaşam kalitesinin geliştirilmesi uygulamalarında önemli rolü bulunmaktadır. Sağlığın geliştirilmesi ise Dünya Sağlık Örgütü tarafından, bireylerin kendi sağlıkları üzerindeki kontrollerini artırmasını sağlayarak sağlık durumlarını geliştirme süreci olarak tanımlanmıştır (Mendi, 2015, s. 279). Bu süreçte bireyler, aktif olarak sağlık bilgisine ulaşmaya çabalayabilir ya da ilgili kişi ve kurumların toplumu bilgilendirme çabalarının hedef kitlesi konumunda olabilirler. İlk durum, sağlık iletişimi literatüründe "sağlık bilgisi arama davranışı" (health information seeking behavior) olarak kavramsallaştırılmıştır. Bu davranışın son yıllarda özellikle internet temelli araçlar (Cline ve Haynes, 2001) ve yakın dönemde ise daha yoğun biçimde sosyal medya (Zhao ve Zhang, 2017) aracılığıyla gerçekleştiği bildirilmiş ve söz konusu mecraların bu kapsamda önemine dikkat çekilmiştir. İkinci durumda ise genellikle farkındalık kavramı ve bu amaçla gerçekleştirilen sağlık iletişimi kampanyaları gündeme gelmektedir. Burada söz edilen kampanya kavramı, tekil bir iletişim uygulamasından öte, birden fazla iletişim aracı ve etkinliğinin stratejik bir bütünlük içerisinde planlanması, uygulanması ve değerlendirilmesi sürecine işaret etmektedir. Diğer pazarlama ve iletişim kampanyalarında olduğu gibi, sağlık iletişimi kampanyaları da geleneksel ve dijital mecraları kullanarak hedef kitlesini etkilemeyi amaçlamaktadır.

Sağlık iletişimi kampanyaları, sağlık açısından risk teşkil eden konuların farkına varılması, toplumsal bilinç ile doğru tutum ve davranış oluşturulması gibi yararlar 
sağlamaktadır (Taşkıran ve Yıldız, 2019). Bu açıdan inme farkındalığı ile kastedilen ve bununla ilgili kampanyalardan beklenen etkiler; belirtilerin tanınması, belirtiler görüldüğünde yapılması gereken doğru davranışın benimsenmesi, risk faktörlerinin bilinmesi ve konunun öneminin farkına varılması şeklinde sıralanabilir (Hickey vd., 2009).

Aslında hasta-doktor iletişimi olarak da adlandırabileceğimiz, sağlık hizmeti alan ve sunan arasındaki iletişim de sağlık iletişiminin önemli bir boyutudur. Sağlık iletişiminin bu boyutu, bireylerarası iletişim bağlamında bu çalışmanın konusu ve kapsamı dışında olsa da farkındalık iletişiminde sağlı profesyonellerinin kullanımı, kaynak güvenilirliği açısından son derece önemlidir. Mesaj kaynağının, "uzmanlık ve güvenilirlik" olmak üzere iki temel niteliğe sahip olmasının sağlı mesajlarına yönelik ilgiyi ve uyumu arttıracağı düşünülmektedir (De Meulenaer vd., 2018). Bu açıdan unvan ya da üniforma gibi otorite sembollerinin de güvenilirliği arttırarak mesaja uyumu kolaylaştırdığı bilinmektedir (Rhoads ve Cialdini, 2002).

\section{Sağlık İletişiminde Sosyal Medya}

Sağlık iletişiminde sosyal medya, gerek kullanıcı katılımı ve etkileşimi ile sağlanan organik iletişim yoluyla gerek daha hedefli ve ölçümlenebilir olan reklam yayınlama olanaklarıyla kullanılmaktadır. Her iki biçimde de sosyal medyanın kendine has özellikleri ve yaygın kullanımı, sağlık iletişimi açısından pek çok firsat yaratmaktadır. Öte yandan sosyal medya ve internet temelli diğer araçların bazı sınırlılıkları ve sorunları olduğunu da belirtmek gerekir. $\mathrm{Bu}$ noktada sosyal medyanın sağlık iletişimi açısından olumlu ve olumsuz taraflarını kısaca tartışmak yararlı olacaktır.

Tosyalı ve Sütçü (2016) sağlıkla ilgili konularda aile, akraba ve arkadaş gibi sosyal etkileşim gruplarının ve tavsiye olgusunun önemini vurgulamış; eskiden bireylerarası iletişime dayalı olarak çalışan bu işleyişin yerini, günümüzde sosyal medya platformlarının aldığını belirtmişlerdir. Sosyal medya, büyük kitlelere ulaşma potansiyeli ve etkileşimli yapısı ile sağlığı geliştirme girişimlerinin iletilmesi adına özgün ortamlar sunmaktadır (Mendi, 2015). Korda ve Itani (2013) sosyal medyanın kullanıcı merkezli ve etkileşime açık yapısı yanı sıra çeşitliliğe sahip ve geniş kitlelere düşük maliyetle ulaşma potansiyeli nedeniyle sağlık iletişimi için oldukça elverişli olduğunu belirtmişlerdir. Bu unsurlara sosyal medya reklam uygulamalarının kullanıcı hedefleme, hedef kitlelere özgü tasarlanmış mesajları iletme ve geribildirimleri derleme gibi olanakları da eklenebilir (Taubenheim vd., 2012). Hatta farkındalık ve bilgilendirme amacina ek olarak belirli bir sağlık problemi ya da riskine sahip bireylere doğrudan ulaşmak ve daha ileri araştırma ya da tedavi süreçlerine katılmalarını sağlamak amacıyla da sosyal medya platformları ve özellikle de hedefli reklam uygulamalarından yararlanılabilir. Bold vd. (2016) tarafindan sigarayı bırakmak isteyen bireylere yönelik gerçekleştirilen çalışma bu uygulamaya güzel bir örnektir. Arigo vd. (2018) söz konusu bu sağlık araştırmaları ve tedavi benzeri uygulamalarla ilgili metodolojik ve etik konuları tartışarak başvuru kaynağı niteliğinde bir makale yayınlamışlardır. ABD Hastalık Kontrol ve Önleme Merkezi (CDC, 2011) de sağlık iletişiminde sosyal medya kullanımının önemine dikkat çekmiş; sosyal medyanın erişimi arttırma, etkileşim yaratma, bilimsel ve güvenilir sağlık mesajlarını ilgili kitlelere iletme gibi açılardan etkili olduğunu vurgulamıştır. Bu kapsamda uzun yıllar sağlık iletişimi kampanyalarını sosyal medya ile bütünleştiren kuruluşun, sağlık iletişimcilerine yönelik bir sosyal medya rehberi yayınlamış olması da bu önemin bir göstergesidir.

Moorhead vd. (2013) sağlık iletişiminde sosyal medyanın kullanımı, yararları ve sınırlılıklarına dair kapsamlı bir değerlendirme ortaya koymuşlardır. Buna göre, sosyal medya ile sağlanan sağlik iletişimi; hastalar, sağlik profesyonelleri ve toplumun geneli 
üzerinde etkili olmaktadır. Bu kitleler sosyal medyayı; çeşitli sağlık konularında bilgi sağlama, tıbbi sorulara yanıt bulma, benzer sağlık problemleri yaşayan kişilerle ya da sağlık profesyonelleri ile iletişim kurma, hastalıklar ya da tedavi uygulamaları hakkında bilgi ve deneyim paylaşma, sağlığı geliştirme, sağlık eğitimi ve doğru uygulamalara yönlendirme, belirli hastalıklara yönelik damgalamanın azaltılması ve online konsültasyon gibi amaçlarla kullanabilmektedir. Bu açıdan sosyal medyanın sağlık iletişimine yararları; kullanıcı etkileşimi sayesinde paylaşılan bilginin etkisini arttırma, farklı hedef kitlelere özel olarak oluşturulmuş mesajları iletme ve toplumun tüm kesimlerine erişim, toplumun geneli ve hastalar için sosyal ve duygusal destek sağlama, çeşitli veri toplama araçları ve karşılıklı iletişim olanakları ile halk sağlığını takip etme ve son olarak sağlık politikalarını etkileme potansiyeli şeklinde sıralanabilir.

Sağlık iletişiminde sosyal medya kullanımının sınırlılıklarına ilişkin kaygılar ise genellikle; dolaşıma giren sağlık bilgisinin niteliği ve güvenilirliği, gizlilik ve mahremiyetin ihlali, kişisel bilgi paylaşımına dair riskler, yanlış ya da zararlı olabilecek tavsiyeler, aşırı bilgi yoğunluğu, online sağlık önerilerinin bireylere özgü sağlık durumlarına uygun olmama olasılığı, tüm bunların sonucu olarak yanlış davranışlar ve istenmeyen sağlık sonuçları ile ilgilidir. Ayrıca sosyal medyanın ve online olarak erişilen bilginin doktora gitme davranışı önünde engel oluşturabileceği ve son olarak sağlık profesyonellerinin de hastalarıyla iletişim kurmak için sosyal medyayı sıklıkla kullanmak istemediği bildirilmiştir (Moorhead vd., 2013). Burada sayılan olumsuz durumlara toplumun farklı kesimleri arasındaki sayısal uçurum olgusu da eklenebilir (Chou vd., 2009). Buna göre, sağlık gibi kritik bir konuda doğru bilgiye yeterli düzeyde erişemeyen bireylerin sağlık hizmetlerinden de etkin biçimde yararlanamayacağı düşünülebilir. Ancak, ülkemiz özelinde internet erişimi, akıllı telefon ve sosyal medya kullanımı istatistikleri incelendiğinde olası bir problemin sayısal uçurum olgusundan ziyade dijital okuryazarlık açısından gündeme geleceği belirtilmelidir. Sosyal medya aracılığıyla paylaşılan sağlık mesajlarının, bu mecranın yapısı gereği bilgi kirliliği ve dezenformasyona yol açabilme riski ise iyi uygulamaların yaygınlaşması ile kısmen de olsa giderilebilecektir. Bu çalışmada incelenen ve konuyla ilgili bilimsel otorite niteliğinde bir sivil toplum kuruluşu tarafından, stratejik bütünlük içinde yürütülen inme farkındalığı kampanyası söz konusu iyi uygulamalara bir örnek olarak değerlendirilebilir.

Toplum sağlığını geliştirme amaçlı her türlü çabanın çok değerli olduğunu not etmekle birlikte, bu konuda özellikle kamu ve sivil toplum kuruluşları tarafından gerçekleştirilen, kurumsal çıkarları ön planda tutmayan ve bilimsel açıdan doğru bilgiyi temel alan çalışmaların ayrı bir yeri olduğunu belirtmek gerekir. Öztürk ve Öymen (2013) Türkiye'de kalp sağlığı konusunda hizmet veren, kâr amacı gütmeyen kuruluşların toplumda kalp sağglığı bilinci ve farkındalığı yaratma amaçlı sosyal medya kullanımlarını incelemiş; sosyal medyanın sağlık iletişiminde stratejik öneme sahip olduğu, ancak söz konusu kuruluşların sosyal medyayı yeterince etkin biçimde kullanamadıkları sonucuna ulaşmışlardır. Bu noktada söz konusu çalışmanın yapıldığı tarihten bu yana gerek sağlık iletişimi alanındaki gelişmeler gerek bu kuruluşların daha profesyonel yaklaşımları sayesinde konuyla ilgili kısa sürede önemli mesafeler kat edildiği de belirtilmelidir.

\section{3. İnme ve İnme Farkındalığı}

Örnek olay olarak ele alınan kampanyayı incelemeye geçmeden önce, kampanyaya konu sağlık problemi olan inme hakkında birtakım temel bilgileri paylaşmak yararlı olacaktır. Bu makalenin bağlamı ve olası okur kitlesi göz önünde bulundurulduğunda bunun için tıp alanından makalelere ve söz konusu alana özgü terminolojiye başvurmak 
yerine, inme hakkında toplumun genelini bilgilendirmek amacıyla TBDHD tarafindan hayata geçirilen web sitesi olan "inme.org.tr" adresindeki bilgilere yer vermenin daha doğru olacağı düşünülmüştür. Bu kaynağa göre inme, beyni besleyen damarlardaki sağlıklı kan akışının, tıkanma ya da kanama gibi nedenlerle kesilmesi sonucu oluşan ve nörolojik fonksiyon kayıplarına yol açan klinik bir durumdur. Halk arasında felç ya da beyin krizi gibi isimlerle de bilinen inme, tüm dünyada kalp hastalıkları ve kanserden sonra üçüncü sıradaki en sık karşılaşılan ölüm nedeni; ülkemizde kalıcı engel nedenleri arasında ise birinci sıradadır. Kolda ya da vücudun bir tarafında ani gelişen güç kaybı, yüzde kayma ve konuşma bozukluğu en sık karşılaşılan inme belirtileridir. $\mathrm{Bu}$ belirtilerden biri fark edildiğinde hastanın vakit kaybetmeden 112 acil sağlı hizmetleri ile inme tedavisi için uygun bir sağlık kuruluşuna ulaştırılması gerekir. Erken müdahale edildiğinde inme, tedavi edilebilir bir problemdir (inme.org.tr, 2021). Dolayısıyla, inme belirtilerinin tanınması ve bu belirtiler fark edildiğinde yapılması gerekenlerin bilinmesi son derece önemlidir. $\mathrm{Bu}$ durum, inme konusundaki farkındalık çalışmalarının önemini de ortaya koymaktadır.

Özellikle İngilizce konuşulan ülkelerde inmenin temel belirtilerini ve yapılması gereken doğru aksiyonu tanımlayan FAST kısaltması, inme farkındalık kampanyalarının ana mesajını oluşturmaktadır. Bu kısaltma; Face (yüzde kayma), Arm (kolda güç kaybı), Speech (konuşma bozukluğu) olmak üzere en sık karşılaşılan inme belirtilerini; Time (zaman) ise inme anında zaman kaybetmeden acil sağlık hizmetine başvurmak gerektiğini özetlemektedir (Flynn vd., 2014). Ülkemiz de dahil olmak üzere, İngilizce dışında diller konuşulan ülkelerde bu kısaltma bir anlam ifade etmiyor olsa da konuyla ilgili farkındalık ve bilgilendirme çalışmalarının temel içeriğini bu mesaj oluşturmaktadır.

Kanser, kalp sağlığı, obezite ya da tütün kullanımı ile mücadele gibi konularda çok sayıda farkındalık çalışması ve bunun sonucunda akademik yayınlar ortaya çıkmıştır. Ancak inme konusunda gerek iletişim kampanyaları gerek konuyla ilgili yayınlar daha sınırlıdır. Başta Avrupa ve Kuzey Amerika ülkelerinde olmak üzere yakın dönemde inme farkındalık kampanyaları ve bu kampanyaların ayrıntıları ya da etkilerine dair akademik çalışmalar gerçekleştirilmiştir. Bu çalışmaların; kaynakları, ülkeleri, kullanılan araştırma yöntemleri ve sonuçları Tablo1'de derlenmiştir. Genel bir değerlendirme ile yürütülen kampanyaların toplumsal farkındalık yaratmada etkili olduğu, ancak bu etkilerin uzun dönemli olmadığı sonucuna varılabilir. Bu nedenle daha kalıcı ve sürdürülebilir bir farkındalık için konuyla ilgili sağlı iletişimi çabalarının sürekli olması gerektiği önerilmektedir.

Tablo 1. İnme Farkındalık Kampanyaları ile İlgili Araştırmalar

\begin{tabular}{|l|l|l|l|}
\hline Kaynak & Ülke & Yöntem - Ölçüm & Sonuç \\
\hline $\begin{array}{l}\text { Silver vd., } \\
2003\end{array}$ & Kanada & $\begin{array}{l}\text { Telefonla anket tekniği ile } \\
\text { kampanya öncesi ve sonrası } \\
\text { farkındalı düzeyi ölçümü }\end{array}$ & $\begin{array}{l}\text { Farklı reklam stratejileri karşılaştırılmış ve } \\
\text { ozzelikle TV reklamlarının inme belirtilerini } \\
\text { tanıma düzeyini arttırdığı bildirilmiştir. }\end{array}$ \\
\hline $\begin{array}{l}\text { Fogle vd., } \\
2008\end{array}$ & ABD & $\begin{array}{l}\text { Telefonla anket tekniği ile } \\
\text { kampanya öncesi ve sonrası } \\
\text { farkındalık düzeyi ölçümü }\end{array}$ & $\begin{array}{l}\text { Kampanyanın, inmenin farklı belirtilerini } \\
\text { tanıma ve 911'i arama gerekliliği hakkında } \\
\text { farkındalık düzeyini arttırdığı bildirilmiştir. }\end{array}$ \\
\hline $\begin{array}{l}\text { Bray vd., } \\
2011\end{array}$ & Avusturalya & $\begin{array}{l}\text { Aylık ambulans çağrı } \\
\text { oranları üzerine retrospektif } \\
\text { araştırma ile kampanya etki } \\
\text { ölçümü }\end{array}$ & $\begin{array}{l}\text { Farkındalık kampanyasının uygulanma } \\
\text { durumu ve mesajlarına paralele olarak inme } \\
\text { nedenli ambulans çağrı oranlarının arttığı } \\
\text { bildirilmiştir. }\end{array}$ \\
\hline $\begin{array}{l}\text { Dombrowski } \\
\text { vd., 2013 }\end{array}$ & İngiltere & $\begin{array}{l}\text { Yarı yapılandırılmış } \\
\text { derinlemesine görüşmeler ile } \\
\text { kampanya etki ölçümü }\end{array}$ & $\begin{array}{l}\text { Kampanyanın inme hakkında temel bilgiler } \\
\text { kazandırmakla birlikte, davranış değişikliği } \\
\text { yaratma etkisinin düşük olduğu bildirilmiştir. }\end{array}$ \\
\hline $\begin{array}{l}\text { Worthmann } \\
\text { vd., 2013 }\end{array}$ & Almanya & $\begin{array}{l}\text { Bilgisayar destekli telefon } \\
\text { anketi ile kampanya öncesi } \\
\text { ve sonrası bilgi düzeyi }\end{array}$ & $\begin{array}{l}\text { Kampanyanın inme risk faktörleri, belirtileri } \\
\text { ve inme anında yapılması gerekenler } \\
\text { hakkında bilgi düzeyinin arttırdı̆̆ }\end{array}$ \\
\hline
\end{tabular}




\begin{tabular}{|l|l|l|l|}
\hline & & ölçümü & bildirilmiştir. \\
\hline $\begin{array}{l}\text { Mellon vd., } \\
2013\end{array}$ & İrlanda & $\begin{array}{l}\text { Kesikli zaman serileri analizi } \\
\text { ile davranışsal değişimlerin } \\
\text { ölçümü }\end{array}$ & $\begin{array}{l}\text { Kampanyayı takiben inme belirtilerini tanıma } \\
\text { ile acil servise başvuruların arttığı, ancak bu } \\
\text { etkinin uzun dönemli olmadığı bildirilmiştir. }\end{array}$ \\
\hline $\begin{array}{l}\text { Flynn vd., } \\
2014\end{array}$ & İngiltere & $\begin{array}{l}\text { Kesikli zaman serileri analizi } \\
\text { ile davranışsal değişimlerin } \\
\text { ölçümü }\end{array}$ & $\begin{array}{l}\text { Kampanya sonucunda ilgili bilgi kaynaklarına } \\
\text { erişim, acil tıbbi hizmetlere başvuru ve tedavi } \\
\text { istatistiklerinde artış bildirilmiştir. }\end{array}$ \\
\hline $\begin{array}{l}\text { Nordanstig } \\
\text { vd., } 2017\end{array}$ & İsveç & $\begin{array}{l}\text { Kampanya öncesi, sırası ve } \\
\text { sonrasında telefonla anket ile } \\
\text { bilgi düzeyi ölçümü }\end{array}$ & $\begin{array}{l}\text { Kampanya sürecinde ve sonrası dönemde } \\
\text { inmeye dair bilgi düzeyinin kısa vadede } \\
\text { arttı̆̆1, ancak daha sonra azaldığ1 } \\
\text { bildirilmiştir. }\end{array}$ \\
\hline
\end{tabular}

Ülkemizde ise çeşitli örneklem gruplarının mevcut inme farkındalığını ölçümlemek amaçlı araştırmalar yapılmış olsa da yurt dışındaki örneklere benzer, kapsamlı bir inme farkındalık kampanyasına ve buna dair bir araştırmaya rastlanmamıştır. Bu çalışma kapsamında örnek olay olarak ele alınan kampanyanın, geleneksel ve dijital mecraları birlikte kullanarak birden farklı şehirde, eş zamanlı ve stratejik bir bütünlük içerisinde gerçekleştirilmiş ulusal çaptaki ilk inme farkındalık kampanyalarından biri olduğu söylenebilir. Bu örnekteki gibi bütüncül bir kampanya biçiminde olmasa da belirli dönemlerde T.C. Sağlık Bakanlığı ve bağlı sağlık müdürlükleri, özellikle bünyesinde inme merkezi olan hastaneler, üniversiteler ya da ilgili sivil toplum örgütleri gibi kuruluşların, toplumu inme konusunda bilinçlendirme amaçlı çalışmalar yaptığı bilinmektedir. Eskişehir ili özelinde inme farkındalığını arttırmak amacıyla Anadolu Üniversitesi İletişim Bilimleri Fakültesi, Eskişehir Osmangazi Üniversitesi Tıp Fakültesi ve Eskişehir İl Sağlık Müdürlüğü iş birliğiyle gerçekleştirilen bir proje de bu çalışmalar arasında sayılabilir (Milliyet, 2018). Bu makalede incelenen kampanyayı hayata geçiren kurum olan TBDHD de 2020 yılı içinde, özellikle Covid-19 pandemisi döneminde inmeyi unutmamak amaçlı bir dizi iletişim etkinliği gerçekleştirmiştir (Topçuoğlu, 2020).

Tıpkı farkındalık çalışmalarının az olması gibi, sağlık iletişimi alanındaki araştırmacıların da inme konusuna yeterince ilgi göstermedikleri söylenebilir. Yukarıda derlenen inme farkındalığı konusunda yapılmış çalışmaların da başta nöroloji ve halk sağlığı bilim dalları olmak üzere büyük oranda tıp alanındaki akademisyenler tarafından gerçekleştirildiği görülmektedir. Özellikle dijital uygulamalar bağlamında gerçekleştirilen sağlık iletişimi araştırmalarına dair kapsamlı bir literatür analizi sunan Hu (2015) mevcut çalışmalarda en fazla ele alınan sağlık konularının; kanser, ruh sağlığı, HIV, beslenme, obezite, fiziksel engellilik, diyabet, alkol ve sigara bağımlılığı olduğunu; kalp hastalığı ve inme gibi kritik sağlık problemlerinin ise görece çok daha az ele alındığını ortaya koymuştur. Yazar, risk grubu yoğunlukla yaşlı bireyler olan bu sağlık problemleri ile ilgili dijital uygulama temelli sağlık iletişimi çalışmalarının az olmasını, yaşılı bireylerin dijital iletişim araçlarını yeterince etkin kullanmadıklarına dair yanlış algı ile ilişkilendirmiştir.

\section{4. Örnek Olay: İnmede Çare Erken Müdahale Kampanyası}

Çalışmada, TBDHD tarafından 2020 yılı Ekim ayı sonunda başlatılan "İnmede Çare Erken Müdahale" adlı inme farkındalığı kampanyası, bir örnek olay olarak incelenmiştir. Uygulamaya dair temel bilgi ve materyaller; kampanyaya özgü oluşturulan mikro site (inme.org.tr), derneğin kurumsal web sitesi (bdhd.org.tr) ve sosyal medya hesaplarından alınmıştır. Sosyal medya reklam uygulamalarına dair veriler ise dernekten alınan izne istinaden, kampanyayı yürüten reklam ajansından temin edilmiştir. $\mathrm{Bu}$ kapsamda, aşağıda sıralanan araştırma sorularını yanıtlamak üzere yine aşağıda ayrıntıları açıklanan örnek olay yöntemine başvurulmuş ve bu doğrultuda bulgular derlenerek yorumlanmıştır. 


\subsection{Araştırma Soruları}

Çalışmada örnek olay biçiminde ele alınan sağlık iletişimi kampanyasıyla ilgili olarak, aşağıda sıralanan araştırma sorularına yanıt aranmaktadır:

1. Kampanya kapsamında kullanılan iletişim stratejisi ve uygulamaları nelerdir?

2. Kampanya kapsamında sosyal medya içerikleri ve reklamları nasıl kullanılmıştır?

3. Sosyal medya reklam uygulamaları ile elde edilen online etkileşim sonuçları nelerdir?

4. Farklı sağlık mesaj içeriklerine yönelik online etkileşim verileri farklılaşmakta midir?

\subsection{Yöntem}

Yin (2018) örnek olayı, güncel olguları kendi gerçek koşulları bağlamında derinlemesine araştıran ampirik bir araştırma yöntemi olarak tanımlamış; bu yönteme başvuran araştırmaların, belirli bir ya da daha fazla olgu ve olaya ilişkin; ne, nasıl ya da neden sorularına yanıt vermeyi amaçlayan açıklayıcı, betimleyici ya da keşfedici nitelikte çalışmalar olabileceğini belirtmiştir. Bu çalışmada tek örnek olay desenine uygun olarak araştırmaya konu sağlık iletişimi kampanyası bir analiz birimi olarak ele alınmıştır.

Araştırma kapsamında örnek olay incelemesi için hem nitel hem nicel yaklaşım birlikte kullanılmıştır. Yin (2018) genellikle nitel araştırma yaklaşımıyla tasarlanan örnek olay araştırmalarında, nicel veriler ya da kanıtların da kullanılabileceğini, hatta incelenen örnek olaya özgü koşullar gerektirdiğinde karma desene başvurulabileceğini belirtmiştir. Bu çalışmada da ilk iki araştırma sorusunu yanıtlamak üzere, örnek olay olarak ele alınan sağlık iletişimi kampanyasının stratejisi, mesaj içerikleri ve yaratıcı uygulamaları nitel bir değerlendirme ile analiz edilmiştir. Son iki soruya ilişkin online etkileşim çıktıları ise sosyal medya platformları tarafından sağlanan nicel verilerden yararlanılarak analiz edilmiştir. Korda ve Itani (2013) sosyal medya aracılığıyla yürütülen sağlık iletişimi kampanyalarının etkilerini değerlendirirken; web sitesi ziyaretleri, gösterimler ve belirli içeriklerin izlenme süresi gibi online etkileşim metriklerinin kullanılabileceğini belirtmişlerdir. Bu kapsamda, sosyal medya reklam uygulamaları ile elde edilen online etkileşim sonuçları betimsel istatistik tablosu ile sunulmuş; farklı reklam içeriklerinin online etkileşim çıktıları bu veri üzerinden değerlendirilmiştir.

\subsection{Bulgular ve Yorum}

Kampanyanın ayrıntılarını incelemeden önce ana hatlarını belirlemek, gerek kampanyaya dair genel bir çerçeve çizmek gerek yapılan analizin temel bileşenlerini ortaya koymak adına yararlı olacaktır. Kurumsal web sitesinin "Hakkımızda"" sayfasında paylaşılan bilgiye göre, öncelikli amacı "beyin damar hastalıklarının oluş nedenleri, koruyucu önlemler ve tedavi yöntemlerine ilişkin bilgileri arttırmak" olan TBDHD bu alanda akademik çalışmaların yanı sıra toplumu bilgilendirme amaçlı faaliyetler de yürütmektedir. Geçmişte de farkındalık amaçlı çalışmalar yürütmüş olan derneğin, 2020 yılında bu çabaları arttırdığı anlaşılmaktadır. Bu kapsamda, pek çok ülkede "Dünya İnme Günü" olarak kabul edilen 29 Ekim tarihi referans alınarak bu çalışmaya konu kampanya hayata geçirilmiştir. $\mathrm{Bu}$ tarihte, toplumu inme konusunda bilgilendirmek amaciyla tasarlanan mikro site (inme.org.tr) yayına başlamış; kampanyanın iletişim stratejisi doğrultusunda offline ve online mecralar birlikte kullanılarak reklam uygulamaları

\footnotetext{
${ }^{1}$ https://bdhd.org.tr/hakkimizda/
} 
gerçekleştirilmiş; özellikle medya ilişkileri ve duyurum bağlamında halkla ilişkiler faaliyetleri yürütülmüş ve sosyal medya içerik yönetimi ile farkındalık iletişimi sürdürülmüştür. Kampanya ağırlıklı olarak sosyal medya üzerinden yürütülmüş olsa da aşağıda ayrıntılı olarak açıklandığı gibi farklı şehirlerde açık hava reklam alanları ve dijital ekran kullanımlarıyla desteklenmiştir.

$\mathrm{Bu}$ doğrultuda örnek olay incelemesinin temel bileşenleri şu şekilde sıralanabilir:

- Kampanyanın iletişim stratejisi ve mesaj içerikleri

- Yaratici uygulamalar ve tasarımlar

- Sosyal medya dişında kalan diğer mecralardaki uygulamalar

- Sosyal medya içerikleri ve reklam uygulamaları

- Online etkileşim sonuçları

Kampanya iletişim stratejisi ve mesaj içeriklerini değerlendirmeye kampanyanın adı olarak da kabul edilebilecek olan slogan üzerinden başlanabilir. Kampanyanın ana mesajını içeren "İnmede Çare Erken Müdahale" ifadesi slogan olarak belirlenmiş ve tüm içeriklerde kullanılmıştır. Bu slogan Görsel 1'de görüldügü gibi, logo biçiminde bir tasarımına da dönüşmüş; kampanyanın ana görseli olarak durağan ve hareketli tüm tasarımların yanı sıra inme.org.tr adresinde dernek logosu ile birlikte kullanılmıştır.

Görsel 1. Kampanya Logosu

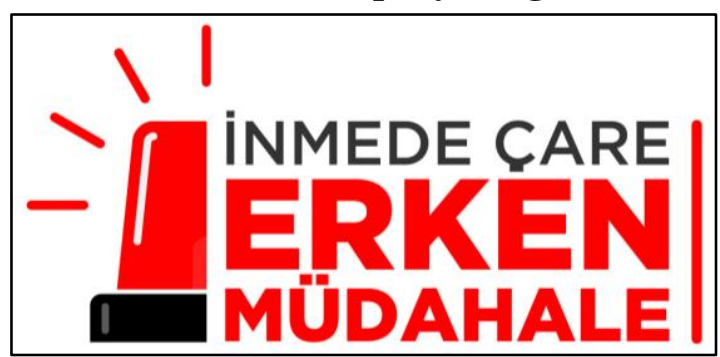

Literatür bölümünde değinildiği gibi, "inme farkındalığı" konusunda toplumla paylaşılması beklenen en temel bilgi; inme belirtilerinin neler olduğu ve bu belirtiler görüldüğünde vakit kaybetmeden acil sağlık hizmetine başvurmak gerektiğidir. Kampanya logosu ve sloganı bu açıdan incelendiğinde; görsel olarak kırmızı ağırlıklı renk kullanımı ve ambulans çağrıştıran siren görselinin, belirtiler görüldüğ̈̈nde yapılması beklenen davranışa gönderme yaptığı söylenebilir. Söylem olarak ise tıpkı kanserle ilgili çalışmalarda "erken tanı" olgusunun yerleştirilmesi gibi, inme konusunda da "erken müdahale" kavramının öne çıkarıldığı görülmektedir. Bu slogan, diğer mesaj içerikleriyle birlikte kullanıldığında ise erken müdahale edilmesi durumunda inmenin çaresinin, yani tedavisinin mümkün olduğunu söylemektedir. Görsel 2'de kampanyanın ana mesaj içeriğini oluşturan unsurları tek bir görselde yansıtan billboard tasarımı gösterilmektedir. $\mathrm{Bu}$ tasarımdaki metin içeriği, başta sosyal medya uygulamaları olmak üzere tüm içeriklerde benzer biçimde yer almıştır. Bu sayede, inme farkındalık kampanyasından beklenen en temel bilgi içeriğinin hedef kitlelere iletildiği söylenebilir. Kampanya bu yönüyle -her ne kadar benzer bir kısaltma kullanılmamış olsa da- klasik bir FAST (Face, Arm, Speech, Time) kampanyası (Flynn vd., 2014) olarak değerlendirilebilir. 
Görsel 2. Billboard Tasarımı

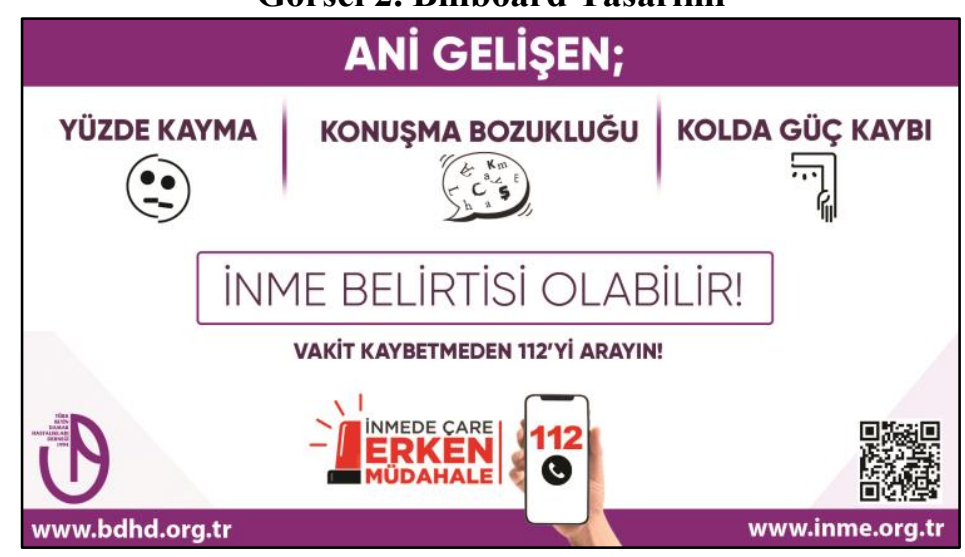

Billboard ve diğer mecralarda kullanılan tasarımlar incelendiğinde, kampanya logosundaki kırmızı dışında, dernek logosu ve kurumsal kimlik tasarımına uygun olan mor rengin ağırlıklı olarak kullanıldığı görülmektedir. Benzer şekilde, belirtileri resmeden ikon biçimli görseller de diğer uygulamalarda durağan görsel ya da video içeriklerde hareketli grafik tasarım unsurları olarak kullanılmışıı. Bu yaklaşımın, hedef kitlelerde hem görsel ve metin içeriği açısından bütünleşik hem de kurumsal görsel kimlik açısından tutarlı bir kampanya izlenimi yaratması olasidır.

Görsel 2'de gösterilen billboard ve bu görseldeki unsurların hareketli grafik tasarıma dönüşmüş 25 saniyelik video versiyonu başta İstanbul, Ankara, İzmir, Bursa, Antalya ve Eskişehir gibi büyük şehirler olmak üzere çeşitli şehirlerde, belediyelerle yapılan iş birlikleri sayesinde billboard ve dijital ekran (meydanlarda ya da toplu taşıma araçlarında bulunan) gibi açık hava reklam alanlarında yayınlanmıştır. Kampanyanın geleneksel medya ayağı büyük oranda bu uygulamalardan oluşmuştur. Bunun yanı sıra, derneğe ait web sitelerinin Medya ${ }^{2}$ ya da Basında $\mathrm{Biz}^{3}$ gibi sayfalarında yer alan içerikler incelendiğinde, derneğin haber değeri taşıyan bu kampanyayı ve ilgili içerikleri basın bülteni ve röportaj gibi araçlarla duyuruma dönüştürdüğü görülmektedir. Kampanyanın halkla ilişkiler boyutu olarak değerlendirilebilecek bu uygulamalarla başta televizyon ve haber siteleri olmak üzere ulusal ve yerel ölçekte görünürlük sağlandığı anlaşılmaktadır.

Kampanyanın bütününe dair bir tablo çizmek adına buraya kadar sosyal medya dışında kalan diğer mecralarda yürütülen uygulamalara dair bilgi verilmiştir. Kampanyanın asıl erişimi sağladığı ve ağırlıklı olarak yürütüldüğü mecra ise sosyal medya platformlarıdır. Bu kapsamda dernek, yukarıda bahsedilen içerikleri de tasarlayan reklam ajansı ile birlikte çalş̧arak etkin bir sosyal medya içerik yönetimi gerçekleştirmeye çabalamış ve kampanya amaçları doğrultusunda sosyal medya reklam uygulamalarına da başvurmuştur. Bu süreç derneğin mevcut kurumsal sosyal medya kanalları olan Facebook, Instagram ve Twitter hesapları üzerinden yürütülmüştür. Her üç platform üzerinden de organik iletişim çabaları sürdürülürken, reklamlar yalnızca Facebook ve Instagram'da sponsorlu içerikler olarak yayınlanmıştır. Sosyal medyada yürütülen iletişim çoğunlukla kampanya web sitesi olan inme.org.tr adresine trafik sağlamak üzere hedeflenmiştir. Gösterim ve erişim hedefli gönderiler ise öncelikli hedefi trafik sağlamak olmasa da adres olarak yine bu web sitesine ziyaretçi yönlendirmiştir.

\footnotetext{
${ }^{2}$ https://www.inme.org.tr/medya

${ }^{3}$ https://bdhd.org.tr/BasindaBiz
} 
Sosyal medya hesapları üzerinden yapılan gerek organik gerek sponsorlu paylaşımların içerikleri incelendiğinde öne çıkan mesajların; temel inme belirtileri, inme anında 112'ye yönlendirme, inme risk faktörleri ve dolayısıyla inmeden korunma yolları, son olarak da inmenin önemi ve olası istenmeyen sonuçlarına dair bilgiler olduğu görülmektedir. $\mathrm{Bu}$ içeriğin genel olarak inme farkındalığı kampanyalarından beklenen temel mesajlar (Hickey vd., 2009) olduğu söylenebilir. Belirtiler ve acil sağlık hizmetine yönlendirme vurgusunun, yukarıda da değinildiği gibi $F A S T$ olarak bilinen içeriğe referansla kullanıldığı ifade edilebilir. İletişim ve mesaj stratejisinin diğer bileşeni olan inme risk faktörleri ise sağlık iletişiminin "risk iletişimi" boyutu ve bu bağlamda sağlik açısından tehdit oluşturan risklere yönelik iletişim süreçlerinin gerekliliği (Taşkıran ve Yıldız, 2009) açısından anlamlı bir içerik olarak değerlendirilmektedir.

Kampanya ana mesajları dışında, derneğin sosyal medya içerikleri incelendiğinde, içinde bulunulan zamana ve gündemdeki konulara uygun olarak inme ile ilişkili paylaşımlar yapıldığı göze çarpmaktadır. 2021 yılı Ocak ayı boyunca sürdürülen "Pandemi Döneminde İnmeden Korunma Stratejisi" konulu içerik serisi buna örnek olarak gösterilebilir. Kampanyanın, Covid-19 pandemisi dönemine denk gelmesi ve pandemi koşullarının inme risk faktörleri ile ilişkisi düşünülerek, konuyla ilgili bilimsel bilgiler sosyal medya paylaşımı için uygun bir formata dönüştürülmüş ve hedef kitle ile paylaşılmıştır. $\mathrm{Bu}$ sayede hedef kitlenin pandemi nedeniyle artan sağlık ilginliğinden yararlanılarak inme hakkında toplumu bilgilendirmek amaçlı bir firsat yaratıldığı düşünülebilir. Benzer şekilde, inme risk faktörleri arasında öne çıkan diyabet ve sigara kullanımı ile ilgili olarak 14 Kasım Dünya Diyabet Günü ve 9 Şubat Dünya Sigarayı Bırakma Günü için özel içerikler paylaşılmıştır. Bu paylaşımlar, günümüzde ticari markaların yanı sıra kâr amacı gütmeyen kuruluşlar tarafindan da kullanılmaya başlanan gerçek zamanlı pazarlama (real-time marketing) uygulama örnekleri olarak değerlendirilebilir. Marka (kurum) mesajlarını gündemdeki olay ya da konularla, zamanlama ve içerik açısından ilişkilendirerek paylaşma biçiminde tarif edilebilecek olan bu uygulamaların, özellikle sosyal medya bağlamında etkili bir içerik stratejisi olduğu bilinmektedir (Willemsen vd., 2018). Burada bahsedilen içerikler dışında, belirli özel günlerle ilgili anma ve kutlama mesajları ile derneğin diğer kurumsal paylaşımlarının sosyal medya hesaplarında yer aldığı belirtilebilir. İçerikler format açısından incelendiğinde ise kampanya mesajlarının genellikle video ve carousel (döngü) formatta tasarlandığı; diğer kurumsal paylaşımların daha çok durağan görsel biçimli olduğu görülmektedir.

Kampanyada sosyal medya reklamlarının kullanımı lansmanı takiben 30 Ekim'de başlamış ve 4 Aralık'ta sona ermiştir. Bu süreçte her biri bir hafta süreyle yayında kalan; üçü video, biri carousel olmak üzere dört farklı içerik kullanılmıştır (Tablo 2). Facebook ve Instagram üzerinde sponsorlu içerik biçiminde yayınlanan bu reklamlar için öncelikle Türkiye geneli, 18 yaş ve üzeri, kadın-erkek gibi geniş bir hedef kitle tanımı yapılmış; daha sonra hedef kitle sağlıkla ilgili anahtar kelimeler üzerinden konuya daha ilgili olma potansiyeli yüksek kullanıcılara daraltılmıştır. Bu hedefleme sürecinde yalnızca inme ya da beyin damar hastalıkları değil, ilgili tüm sağlık konuları kullanılmış; mevcut takipçiler ise organik olarak erişim mümkün olduğu düşünülerek hedef kitle dışında bırakılmıştır. Reklamların tümü aynı hedef kitle tanımıyla, ancak farklı reklam hedefleriyle yayınlanmıştır. 
Tablo 2. Kampanyada Kullanılan Sosyal Medya Reklamlarına İlişkin Temel Bilgiler

\begin{tabular}{|c|l|l|l|l|}
\hline Sıra & Yayın Tarihleri & Reklam İçeriği & Format & Hedef \\
\hline $\mathbf{1}$ & 30 Ekim - 5 Kasım & $\begin{array}{l}\text { Temel belirtileri ve 112'yi arayın mesajını içeren } \\
\text { seslendirmeli masaüstü animasyon lansman filmi }\end{array}$ & $\begin{array}{l}\text { Video } \\
(25 \text { sn. })\end{array}$ & $\begin{array}{l}\text { Trafik } \\
\text { (tıklama })\end{array}$ \\
\hline $\mathbf{2}$ & 6 Kasım - 12 Kasım & $\begin{array}{l}\text { İnme hakkında temel bilgileri içeren durağan } \\
\text { ardışık görseller }\end{array}$ & Carousel & Erişim \\
\hline $\mathbf{3}$ & $\begin{array}{l}\text { 16 Kasım - 22 } \\
\text { Kasım }\end{array}$ & $\begin{array}{l}\text { İnme anında çekinmeden 112'yi arayın temalı } \\
\text { sessiz masaüstü animasyon }\end{array}$ & $\begin{array}{l}\text { Video } \\
(14 \text { sn. })\end{array}$ & $\begin{array}{l}\text { Video } \\
\text { görüntüleme }\end{array}$ \\
\hline $\mathbf{4}$ & 27 Kasım - 4 Aralık & $\begin{array}{l}\text { Uzman doktor anlatımıyla inme hakkında temel } \\
\text { bilgiler içeren canlı çekim video }\end{array}$ & $\begin{array}{l}\text { Video } \\
(60 \text { sn. })\end{array}$ & $\begin{array}{l}\text { Trafik } \\
(\text { tıklama })\end{array}$ \\
\hline
\end{tabular}

Reklamlar için erişim linkleri aşağıda dipnot olarak paylaşılmış olsa da her birinin elde ettiği etkileşimleri değerlendirmeden önce içeriklerini kısaca tarif etmek yararlı olacaktır. İlk reklam ${ }^{4}$ aynı zamanda kampanyanın lansman videosudur ve açık hava reklam içeriği temel alınarak oluşturulmuş, dijital ekran tasarımlarının seslendirilmiş hali olarak tarif edilebilir. Durağan görsellerden oluşan carousel formatlı ikinci reklam ${ }^{5}$, ülkemizde her yıl yaklaşık elli bin kişinin inme nedeniyle hayatını kaybettiğini, ancak erken müdahale ile inmenin tedavi edilebilir olduğunu vurgulamakta; inme belirtilerini ve inme anında 112'yi aramak gerektiği bilgisini içermektedir. Üçüncü reklam ${ }^{6}$, hastaların pandemi koşulları nedeniyle sağlık hizmetlerine başvurmakta tereddüt edebileceği düşüncesinden hareketle inme anında 112'ye başvurmak gerektiğini "çekiNMEden ara" mesajıyla vurgulamaktadır. Son reklam ${ }^{7}$ ise uzman tanıklığına başvurmakta; canlı çekim tekniği ile hazırlanmış videoda, aynı zamanda derneğin yönetim kurulu üyesi de olan Ankara Üniversitesi Tıp Fakültesi Nöroloji Anabilim Dalı Öğretim Üyesi Prof. Dr. Canan Togay Işıkay inme nedenleri, belirtileri, tedavisi, yapılması gerekenler ve risk faktörleri gibi temel bilgileri paylaşmaktadır.

Sosyal medya reklamlarının online etkileşim sonuçlarını içeren yayın performans verileri Tablo 3'te sunulmuştur. Buna göre dört reklam ile toplamda 1.316 .874 gösterim elde edilmiş; 760.934 tekil kullanıcı erişimi sağlanmıştır. Reklamlar toplamda $12.379 \mathrm{kez}$ tıklanmış ve kampanya web sitesine trafik sağlamıştır. Reklamların etkileşim oranlarını karşılaştırmaya geçmeden önce dört reklam yayınının birlikte kampanyaya olan genel etkilerini değerlendirmek yararlı olacaktır. Öncelikle yukarıda verilen gösterim ve erişim sayıları, derneğin bu reklam kampanyası ile mevcut takipçileri dışında kalan çok daha geniş bir kitleye ulaştığını göstermektedir. Sosyal medya platformundan elde edilen rapor, reklamların coğrafi dağılım verilerini de içermektedir. Buna göre, reklamlardan en az biri Türkiye'nin 81 ilinde, hedef kitle kapsamına giren sosyal medya kullanıcılarına gösterilmiş ve inme.org.tr adresine her ilden ziyaretçi çekilmiştir. Gösterim ve tıklama verileri nüfus verilerine paralel bir seyir izlemiş; en yüksek etkileşim sırasıyla İstanbul, Ankara, İzmir, Bursa gibi büyük şehirlerden; en düşük ise Ardahan, Hakkâri, Gümüşhane, Muş, Iğdır, Tunceli ve Bayburt şehirlerinden gelmiştir. Bu süreçte inme.org.tr sitesi de analitik araçları ile izlenmiş ve ziyaret istatistikleri tutulmuştur. $\mathrm{Bu}$ verilere göre, reklam yayınlanan dönemde (30 Ekim - 4 Aralı) kampanya web sitesi toplamda yaklaşık olarak $16.000 \mathrm{kez}$ ziyaret edilmiştir. Yalnızca reklamların toplamda 12.379 kez tıklanmış olduğu düşünülürse, bu süreçte siteye gelen tüm trafiğin \%75'inden fazlasının sosyal medya reklamları kaynaklı olduğu anlaşılacaktır.

\footnotetext{
${ }^{4}$ https://www.facebook.com/TurkBeyinDamarHastaliklariDernegi/videos/365069504802020/

${ }^{5}$ https://www.facebook.com/TurkBeyinDamarHastaliklariDernegi/photos/pcb.3853983134632397/3853981707965873

${ }^{6}$ https://www.facebook.com/TurkBeyinDamarHastaliklariDernegi/videos/829009997910561/

${ }^{7}$ https://www.facebook.com/TurkBeyinDamarHastaliklariDernegi/videos/286120979503341/
} 
Tablo 3. Sosyal Medya Reklamlarının Yayın Performansı

\begin{tabular}{|l|c|c|c|c|}
\hline $\begin{array}{l}\text { Performans } \\
\text { Göstergesi }\end{array}$ & $\begin{array}{c}\text { 1. Kampanya } \\
\text { Lansman Filmi }\end{array}$ & $\begin{array}{c}\text { 2. Carousel } \\
\text { (Döngü) Reklam }\end{array}$ & $\begin{array}{c}\text { 3. Çekinmeden } \\
\text { 112'yi Arayın }\end{array}$ & $\begin{array}{c}\text { 4. Uzman Doktor } \\
\text { Anlatımı }\end{array}$ \\
\hline Gösterim & 305.008 & 159.332 & 569.708 & 282.826 \\
\hline Erişim & 168.880 & 157.200 & 275.008 & 159.846 \\
\hline S1klık & 1,81 & 1,01 & 2,07 & 1,77 \\
\hline Tiklama & 2812 & 1477 & 2580 & 5510 \\
\hline Video izleme & 48.160 & - & 181.733 & 68.636 \\
\hline Video tamamlama & 7.156 & - & 67.197 & 11.897 \\
\hline $\begin{array}{l}\text { CTR - Tiklamanın } \\
\text { gösterime oranı }\end{array}$ & $\% 0,92$ & $\% 0,93$ & $\% 0,45$ & $\% 1,95$ \\
\hline $\begin{array}{l}\text { Tiklamanın izlemeye } \\
\text { oranı }\end{array}$ & $\% 5,84$ & - & $\% 1,42$ & $\%, 03$ \\
\hline $\begin{array}{l}\text { İzlemenin gösterime } \\
\text { oranı }\end{array}$ & $\% 15,79$ & - & $\% 36,98$ & $\% 17,33$ \\
\hline $\begin{array}{l}\text { Video tamamlama } \\
\text { oranı }\end{array}$ & $\% 14,86$ & - & & $\% 24,27$ \\
\hline
\end{tabular}

Reklamların gerek biçim ve içerikleri gerek reklam hedeflerinin birbirinden farklı olması elde ettikleri etkileşim sonuçlarını da farklılaştırmıştır. Aynı hedef kitleye, birbirine çok yakın bütçelerle yayınlanmış olsalar da her reklam kendi hedefleri doğrultusunda farklı gösterim, erişim, tıklama ve izleme sonuçları elde etmiştir. Bilindiği gibi sosyal medya platformları, reklam yayınlarını reklamveren tarafından belirlenen hedefler doğrultusunda optimize etmektedir. Bu kampanyada da örneğin; aynı kişiye reklamı birden fazla kez gösterip göstermeme durumunu açıklayan sıklık verileri reklam yayın algoritmasının nasıl çalıştığını göstermektedir. Tablo 3'te de görüldüğü gibi, siteye trafik sağlama hedefiyle yayınlanan ilk ve son reklamların sıklık değerleri $(1,81$ ve 1,77$)$ birbirine çok yakın iken; erişim hedefiyle yayınlanan, yani olabildiğince çok sayıda tekil kullanıcıya erişmeyi hedefleyen ikinci reklamın neredeyse her kullanıcıya yalnızca bir kez $(1,01)$ gösterildiğ $i$ görülmektedir. Erişim sıklığını göz ardı edip, videoyu olabildiğince fazla kez izletmek amacıyla yayınlanan üçüncü reklam ise bu amaca uygun bir sonuç $(2,07)$ ortaya koymuştur.

Sosyal medya reklamlarının en temel performans göstergelerinden biri CTR (Clickthrough rate) olarak bilinen, tıklamaların gösterime oranıdır. Buna göre, en yüksek CTR değerini elde eden reklam, uzman tanıklığına başvuran son reklamdır $(\% 1,95)$. Bu konuda üçüncü reklamın en düşük performansı $(\% 0,45)$ göstermiş olması da yine bu reklamın hedefi ile ilgili olabilir. Söz konusu reklamın tıklama verisinin aksine, diğer tüm video reklamlara kıyasla daha fazla izlenmiş olduğu bu yorumu desteklemektedir. Neredeyse aynı oranda tıklanmış olan ilk iki reklamın CTR değerleri $(\% 0,92$ ve $\% 0,93)$ ise tüm kampanyanın ortalama CTR değeri olan \%0,94 oranına oldukça yakındır.

İkinci sırada yayınlanan carousel reklam dışındaki diğer üç reklamın formatı videodur. $\mathrm{Bu}$ nedenle gösterimin yanı sira izlenme verisi de reklam performans değerlendirmesi için önemli bir parametredir. Uygulamada genel bir kabul olarak video biçimli bir reklamın üç saniye ve daha fazla süreyle izlenmesi bir "izleme" olarak değerlendirilmektedir. Buna göre, her biri farklı sürelerde tasarlanmış videolar olsalar da kampanyanın üç farklı video reklam içeriği toplamda 298.529 kez izlenmiştir.

Farkındalık iletişimi bağlamında reklama maruz kalan kullanıcıların içeriği ne süreyle izlediği, kampanya mesajlarının ne kadarının iletilmiş olduğu açısından önemlidir. Tablo 3'te her bir video için ayrıca belirtilen video tamamlama sayıları toplandığında, videoların $86.250 \mathrm{kez}$ sonuna kadar izlendiği ve bu kullanıcılara kampanya mesajlarının tamamının iletildiği söylenebilir. Reklam içeriklerini kıyaslamak için ise her bir reklamın 
kaç kez izlendiği ya da tamamlandığından öte, bu sayıların gösterime olan oranlarını ele almak daha anlamlı bir sonuç ortaya koyacaktır. Bu noktada daha önce de değinildiği gibi, reklam hedeflerindeki farklılaşmanın, sonuçlar üzerinde de farklılık yarattığını göz önünde bulundurmak gerekir. Yukarıda üçüncü reklamın bu açıdan ortaya koyduğu farklı sonuçlar ayrıca açıklanmıştır. İlk ve son reklamlar ise gerek reklam hedefi gerek format açısından benzerdir. Bu videolar arasındaki fark yalnızca içerikleridir. Kampanya lansman videosu da olan ilk reklam, kampanya mesajlarını masaüstü animasyon biçiminde sunarken; son reklamda bu mesajlar uzman tanıklığı kullanılarak, daha ayrıntılı biçimde ve canlı çekim tekniği ile üretilen bir videoda sunulmuştur. Dolayısıyla bu reklamların elde ettikleri online etkileşimler arasındaki olası bir farkın büyük oranda içerik kaynaklı olacağı düşünülebilir.

Görsel 3. Lansman Videosu ve Uzman Doktor Videosu Ekran Görüntüleri
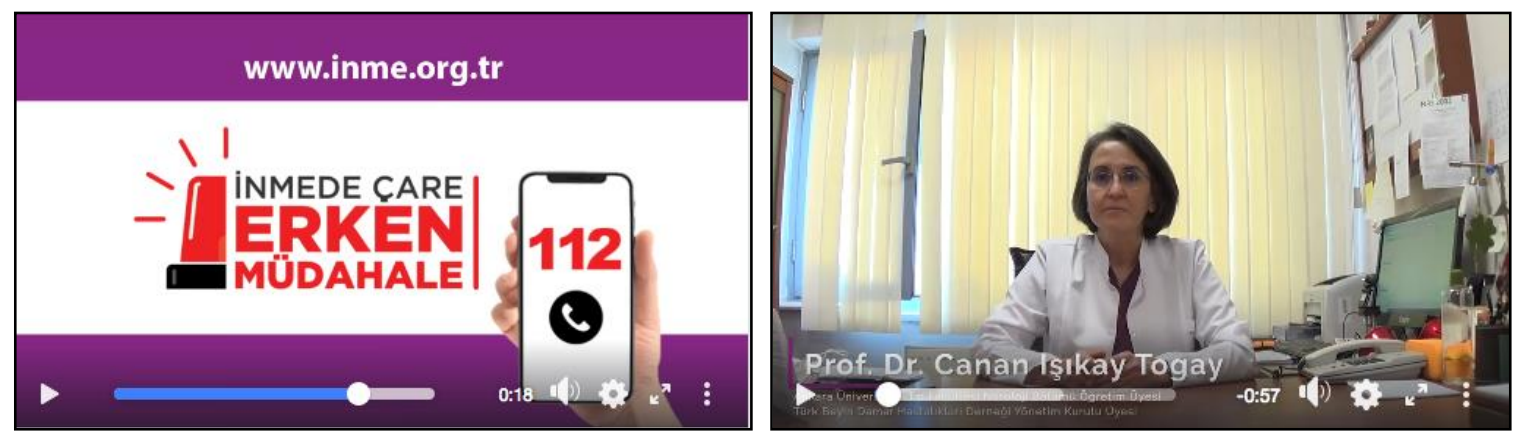

Sağlık iletişiminde sosyal medya reklamları kullanımına odaklanan bu çalıșmada hangi içeriklerin nasıl sonuçlar elde ettiğine dair anlamlı bir bulgu ortaya koyabilmenin önemli olduğu düşünülmektedir. Görsel 3 'te paylaşılan ekran görüntülerinde de görüleceği gibi, soldaki lansman videosundan farklı olarak sağdaki içerikte bir uzman, doktor önlüğü ile hastane odasından bilgi vermektedir. Unvanı ve çalıştığ konunun uzmanı olduğu anlaşılan doktorun anlatımına dayalı videonun diğer içeriklerden farklı bir performans ortaya koyması beklenmektedir. Tablo 3 'te paylaşılan etkileşim oranlarına bakıldığında bu reklamın; tıklanma, izlenme ve tamamlanma oranlarının özellikle ilk reklama kıyasla yüksek olduğu görülecektir. Bu noktada, söz konusu iki reklam arasındaki farkların istatistiki açıdan anlamlı olup olmadığı sorusu akla gelmektedir. Bu soruyu yanıtlamak amaciyla, sosyal medya platformu tarafından sağlanan rapordaki veriler SPSS programı üzerinde analiz edilebilecek bir forma dönüştürülmüştür. Raporda verilen gösterim, izleme, tıklama gibi veriler baz alınarak, reklama maruz kalan kullanıcıların reklamı izleyip izlemediği ya da tıklayıp tıklamadığı açısından ortaya çıkan frekans verileri kategorik değişken olarak düzenlenmiş ve Chi-Square (Ki-Kare) testi ile analiz edilmiştir.

Tablo 3'te de görüleceği gibi, son reklamın elde ettiği tıklamalar, oran olarak ilk reklamın elde ettiğinin iki katından fazladır. Aradaki belirgin farkın istatistiki açıdan da anlamlı olması $\left(\chi^{2}=1107.395, s d=1, p<0.001\right)$ sağlık iletişiminde uzman tanıklığının rolünü ortaya koymaktadır. İçeriğin video olduğu düşünülerek tıklama verisi, gösterimin yanı sıra izleme verisi temel alınarak da hesaplanmıştır. Bir başka ifadeyle tıklama oranı, reklamı en az üç saniye izleyen kullanıcılar açısından ayrıca hesaplanmıştır. Bu durumda da son reklam ilk reklamdan daha yüksek bir tıklama performansı göstermiştir $\left(\chi^{2}=\right.$ 204.927, $s d=1, p<0.001)$. Bu sonuçlara göre, sosyal medyada sağl1k ile ilgili bilgilerin bir doktor tarafından anlatılmasının, masaüstü animasyon biçiminde anlatıma kıyasla kullanıcıları daha fazla bilgi almak üzere hedef web sitesine daha yüksek oranda yönelttiği söylenebilir. 
Video içerikler söz konusu olduğunda diğer önemli performans göstergeleri ise reklamı görenlerin ne oranda izlediği ve izlemeye başlayanların ne oranda sonuna kadar izlediğidir. Bu açıdan bakıldığında, son reklamın ilk reklamdan daha az gösterime rağmen daha fazla izlendiği söylenebilir. İzlenme oranları açısından ortaya çıkan fark $\left(\chi^{2}=\right.$ 6625.308, $s d=1, p<0.001)$ doktor tarafından anlatılan bilgilerin daha fazla dikkat çektiği şeklinde yorumlanabilir. Video tamamlama oranları arasındaki fark $\left(\chi^{2}=126.955, s d=1\right.$, $p<0.001)$ da benzer bir duruma işaret etmektedir. Buna göre, sağlık bilgisinin bir uzman doktor tarafından anlatıldığında daha fazla ilgi çektiği ve daha uzun süre izlendiği sonucuna ulaşılabilir.

Çalışmada son olarak reklam kampanyasının kurumun takipçi sayıları üzerindeki etkisi değerlendirilmiştir. Bilindiği gibi bir kurumun, hesabını takip eden kullanıcılar ile iletişim kurması, onlara yönelik içerik paylaşarak etkileşim yaratma firsatı açısından oldukça önemlidir. Bu çalışmaya konu kampanya sürecinde ücretli ya da organik biçimde takipçi arttırmaya yönelik özel bir çaba sarf edilmemiştir. Buna rağmen, reklamların yayında olduğu süreçte derneğin takipçi sayılarının Facebook'ta \%5,16; Instagram'da ise \%12,6 oranında arttığı görülmüştür. Bu durum, derneğin reklam kampanyası sayesinde, daha önce hiç temas etmemiş olduğu yeni kullanıcılara ulaşmış olduğunu düşündürtmektedir.

\section{Sonuç, Tartışma ve Öneriler}

$\mathrm{Bu}$ çalışmada, sağlık iletişiminde sosyal medya reklamları kullanımı konusunda bir örnek olay olarak TBDHD tarafından yürütülen inme farkındalığı kampanyası incelenmiştir. 2020 yılı Ekim ayı sonunda başlayan kampanyada, Aralık ayı başına kadar geçen süreçte Facebook ve Instagram platformları üzerinde reklam uygulamaları da gerçekleştirilmiştir. Reklam kampanyası sona ermiş olsa da bu makalenin hazırlandığı dönemde kampanya mesajlarını da içeren farkındalık iletişimi çalışmaları özellikle sosyal medya içerik yönetimi kapsamında sürdürülmektedir. Bu çalışmayla bir sivil toplum örgütü tarafından gerçekleştirilmiş olan kampanya örneği üzerinden gerek sağlık iletişimi alanına gerek bu kapsamda sosyal medya reklamları kullanımına dair çıkarımlar sunulmaktadır.

Tosyalı ve Sütçü (2016) sağlık iletişiminde sosyal medyanın öneminin farkına varan sağlık kuruluşları, ilaç şirketleri ve gönüllü toplulukların, çeşitli hastalıkları gündemde tutmak ve bu hastalıklara karşı toplumu bilinçlendirmek için sosyal medya araçlarını kullanarak kampanyalar yürüttüğüne dikkat çekmişlerdir. Bu noktada ticari kurumlar ile kâr amacı gütmeyen kurumların, benzer uygulamaları farklı amaçlarla gerçekleştirdiklerini vurgulamak gerekir. Temel misyonu beyin damar hastalıkları konusunda akademik ve toplumsal çalışmalar yapmak olan TBDHD "inme sıklığını azaltmayı ve inmeyi ülkenin her köşesinde tedavi edilebilir hale getirmeyi hedeflediğini" belirtmektedir (inme.org.tr, 2021). Bu kampanya da derneğin burada tarif ettiği hedefle ilişkili, toplum yararı gözeten bir çalışma olarak değerlendirilebilir. Buradaki örnekten farklı olarak, kimi zaman ticari kurumlar ile sivil toplum kuruluşlarının ortak amaçlarla hareket ederek sponsorluk ilişkisi ya da benzeri biçimlerde sağlık iletişimi uygulamaları gerçekleştirmeleri de olasıdır. Böylesi örnekler, bir yönüyle toplumsal sağlığa fayda sağlarken, bir yönüyle de ticari kurumların varlığını sürdürebilme, karlılığı arttırma ve yatırımın geri dönüşü gibi kazanımları açısından anlamlı olabilir.

Kim tarafindan gerçekleştirildiğinden bağımsız olarak buradaki örneğe benzer çalışmaların topluma fayda sağlamak adına anlamlı olacağını belirtmek gerekir. Taşkıran ve Yıldız'ın (2019) çalışması, sağlık iletişimi kampanyalarının sağlığa ilişkin risk teşkil 
eden konuların farkına varılması ve bilinç geliştirilmesinde etkili olduğunu; bu kapsamda özellikle web siteleri ve sosyal medya platformları gibi yeni medya ortamlarının etkili iletişim araçları olduğunu ortaya koymuştur. Şener ve Samur'un (2013) sağlık temalı Facebook hesapları üzerine yaptığı inceleme ise sağlık iletişimi bağlamında sosyal medya kullanımının olumlu yönleri yanı sıra birtakım sakıncalarını da ortaya koymaktadır. Araştırmada özellikle, informal iletişime dayalı söz konusu hesaplarda paylaşılan bilgilerin; kaynağı, doğruluğu ve ticari amaç içeriği gibi açılardan problemleri tartışılmıştır. Söz konusu tartışma, bu çalışmada bir örnek olay olarak incelenen sağlık iletişimi kampanyasında olduğu gibi, ilgili sağlık konusunda otorite olan, doğru ve bilimsel bilgiye başvuran ve kâr amacı gütmeyen kurumların uygulamalarının gerekliliğini ve önemini de ortaya koymaktadır.

$\mathrm{Bu}$ çalışmanın bulguları, kampanyanın hedef kitle üzerinde yarattığı farkındalık, tutum ya da davranış değişikliği gibi etkilerini kapsamamaktadır. Araştırmanın kapsamı ve yöntemi bu değişkenler açısından kampanya etkilerini açıklamıyor olsa da kampanyanın içeriği, erişimi ve maruz kalanların online davranışsal tepkileri üzerinden bir değerlendirmeyi mümkün kılmaktadır. Bu açıdan bakıldığında ilk olarak kampanya sonucunda gerek sayı gerek coğrafi açıdan kurumun mevcut erişiminin çok ötesinde bir kitleye ulaşıldığ 1 söylenebilir. İnme gibi kritik öneme sahip bir sağlık konusunda toplumun tüm kesimlerini bilgilendirmek gerektiği düşünülürse, kampanya ile söz konusu sağlik problemine dair toplumsal farkındalık adına önemli bir adım atıldığı belirtilebilir. Kampanya stratejisi ve mesaj içeriği ise yukarıda ayrıntılı olarak değerlendirildiği gibi, başta FAST mesajı (Flynn vd., 2014) olmak üzere inme farkındalığı kampanyalarından beklenenleri (Hickey vd., 2009) karşılamaktadır. Buna ek olarak kampanya sürecinde yayınlanan; pandemi, diyabet ve sigara kullanımı gibi konularla ilgili içerikler de inme konusuna dikkat çekmek adına yapılan gerçek zamanlı pazarlama uygulamaları olarak değerlendirilmiştir.

Kampanya ile offline ve online tüm kanallarda iletilen mesajlar, alıcıları toplumu inme konusunda bilgilendirmek üzere tasarlanan mikro siteye yönlendirilmiştir. Kampanya sürecinde, site trafiğinin çok büyük oranda sosyal medya reklamlarından sağlanmış olması sosyal medya reklamlarının kampanyaya olan katkısını ortaya koymaktadır. Başta sosyal medya (Zhao ve Zhang, 2017) olmak üzere web sitesi gibi internet temelli araçların (Cline ve Haynes, 2001) sağlık bilgisi arama davranışı açısından önem kazandığı bilinmektedir. Bu noktada kampanyanın özellikle sosyal medya reklamları ile bu davranışı pekiştirdiği ve kolaylaştırdığı ifade edilebilir.

Sosyal medya reklamlarının elde ettiği online etkileşim sonuçları incelendiğinde ise ilk olarak sonuçların reklam hedeflerine paralel olduğu dikkat çekmektedir. Sosyal medya reklamcılığı açısından son derece beklendik olan bu durum sağlık iletişimi gibi konularda gerçekleştirilen toplumsal kampanyalar için özel bir anlam ifade edebilir. Toplumsal amaçlı kampanyaların; bilgi paylaşımı, destekçi ya da bağış toplama, ürün satışından gelir elde etme gibi farklı hedefleri söz konusu olabilir. Bu noktada farklılaşan hedeflere yönelik reklam hedefleme ve optimizasyon olanağı sağlayan sosyal medya reklamcılı̆̆ı, ticari markaların yanı sıra kâr amacı gütmeyen kurumlar için de yararlı olacaktır.

Çalışmanın en önemli sonuçlarından biri, farklı sağlık mesaj içeriklerine yönelik online etkileşim verilerinin farklılaştığının ortaya koyulmasıdır. Aynı hedef kitleye yönelik olarak, aynı hedeflerle yayınlanan reklamların farklı sonuçlar elde etmiş olması, bu farkın söz konusu reklamların içeriği ile ilgili olduğunu düşündürtmektedir. Bu kapsamda, uzman tanıklığına başvurarak, sağlık mesajlarını bir doktorun anlatımıyla sunan video içerik, 
benzer mesajları masaüstü animasyon biçiminde sunan videodan anlamlı düzeyde daha fazla izlenme, video tamamlama ve tıklama etkileşimi elde etmiştir. Bu durum, sağlik iletişiminde kaynak güvenilirliği olgusu ile ilişkilendirilebilir. Konu uzmanı olduğu anlaşılan güvenilir bir kaynaktan gelen bilgilerin, sağlık mesajlarına yönelik ilgiyi ve uyumu arttıracağı (De Meulenaer vd., 2018); unvan ve üniforma gibi otorite sembollerinin ise güvenilirliği arttırarak mesaja uyumu kolaylaştıracağı (Rhoads ve Cialdini, 2002) öngörülmektedir. İzleme ve tıklama davranışlarının içeriğe yönelik ilgi ve mesaja uyumla ilişkili olduğu düşünülebilir. Dolayısıyla, araştırma sonuçlarının sağlık iletişiminde kaynak güvenilirliği açısından önceki çalışmalarla tutarlı olduğu ve bu durumu güncel bir örnek üzerinden açıkladığı ifade edilebilir.

Sosyal medyada kurumlar tarafından yayınlanan içerikler, takipçiler tarafindan yeniden paylaşılabilmekte ve onların takipçilerine de iletilmektedir. Bu kampanyada da başta mevcut takipçiler içinde yoğun olarak bulunan doktorlar olmak üzere diğer kullanıcılar tarafından kampanya mesajlarının paylaşılması, sağlık bilgisinin daha fazla kişiye ulaşması ve yaygın etkinin arttırılması açısından önemlidir. Sosyal medyanın en temel dinamiklerinden birinin bu etkileşim olanağı olduğu açıktır. Ancak bu çalışma kapsamında kampanya içeriklerinin elde ettiği organik etkileşim incelenmemiştir. Konuyla ilgili yeni araştırmaların bu değişkeni içermesi, reklam dışında kalan sosyal medya sağlık iletişimi içeriklerinin etkilerini ortaya koymak adına anlamlı olacaktır. Her ne kadar organik etkileşime dair veriler çalışmanın kapsamı dışında olsa da kampanya sonunda kurumun mevcut takipçi sayısının arttı̆̆ belirtilmelidir. Yeni takipçilerin, yeni etkileşim firsatları yaratacağı göz ardı edilmemelidir.

Diğer tüm dijital mecralarda olduğu gibi, sosyal medya aracılığıyla gerçekleştirilen iletişim uygulamalarının sonuçları da geleneksel mecralara kıyasla daha ölçümlenebilir niteliktedir. Sağlık iletişimi çabalarının etkilerini değerlendirmek açısından bu konu oldukça önemlidir. Özellikle reklam ve benzeri ücretli iletişimle elde edilen erişim, etkileşim, site trafiği gibi online veriler kolaylıkla raporlansa da bunun gerçek yaşamdaki sağlık etkilerini ve yarattığı davranışları ölçümlemek zor olabilir (CDC, 2011, s. 6). Bu etkiler, iletişim uygulamalarının hedeflediği kitlenin tutum ve davranışları üzerinden değerlendirilebilir. Kampanyanın uygulandığ 1 alanda toplum genelinde oluşması beklenen davranışsal değişimler hastane kayıtları ya da ilgili diğer istatistikler açısından incelenebilir. Belirli bir kampanya örnek olay olarak ele alındığında da özellikle davranış öncülü tutum ve bilgi düzeyi açısından oluşan etkiler, online paneller ya da anket benzeri araçlarla hedef kitle gruplarından veri toplanarak da değerlendirilebilir (Evans vd., 2008). İnme farkındalığı konusunda farklı ülkelerde gerçekleştirilmiş kampanyaların etkileri burada söz edilen yöntemlerle incelenmiştir (Bkz. Tablo1). Bu gibi kapsamlı çalışmaların ülkemizde de yapılması gerek toplumun inme farkındalık düzeyini daha geniş çaplı biçimde ölçümlemek gerek yürütülen kampanyaların etkilerini daha net ortaya koymak adına yararlı olacaktır.

Farklı ülkelerde yapılan çalışmalar, sosyal medya araçlarının kullanımı ile sağlık davranışlarının olumlu yönde değiştirilebileceğini, sağlık eğitimi ve hastalıkların önlenmesi adına avantajlar sağlanabileceğini göstermiştir (Mendi, 2015). Bu çalışmada örnek olay olarak incelenen kampanya benzeri yeni çalışmaların hayata geçirilmesi, sağlık ve ilgili diğer konularda topluma önemli katkılar sağlayacaktır. Son olarak, inme gibi toplumun hakkında yeterince bilgi sahibi olmadığı konularda etkin bir farkındalık düzeyini yakalayabilmek için bu gibi çabaların sürekli hale getirilmesi gerektiği belirtilmelidir. 


\section{Teşekkür}

Yazar, incelenen kampanyaya ilişkin bilgi, görsel ve verilerin paylaşımına olanak sağlayan Türk Beyin Damar Hastalıkları Derneği'ne teşekkür eder.

\section{Kaynakça}

Arigo, D., Pagoto, S., Carter-Harris, L., Lillie, S. E. and Nebeker, C. (2018). Using social media for health research: Methodological and ethical considerations for recruitment and intervention delivery. Digital Health, 4, 1-15.

Avcı, K. ve Avşar, Z. (2014). Sağlık iletişimi ve yeni medya. İletişim Kuram ve Araştırma Dergisi, 39, 181-190.

Bold, K. W., Hanrahan, T. H., O'Malley, S. S. and Fucito, L. M. (2016). Exploring the utility of web-based social media advertising to recruit adult heavy-drinking smokers for treatment. Journal of Medical Internet Research, 18(5), e107.

Bray, J. E., Mosley, I., Bailey, M., Barger, B. and Bladin, C. (2011). Stroke public awareness campaigns have increased ambulance dispatches for stroke in Melbourne, Australia. Stroke, 42(8), 2154-2157.

CDC (2011). The health communicator's social media toolkit. https://www.cdc.gov/ healthcommunication/ToolsTemplates/SocialMediaToolkit_BM.pdf, Erişim Tarihi: 30.01.2021.

Chou, W. Y. S., Hunt, Y. M., Beckjord, E. B., Moser, R. P. and Hesse, B. W. (2009). Social media use in the United States: İmplications for health communication. Journal of Medical Internet Research, 11(4), e48.

Cline, R. J. and Haynes, K. M. (2001). Consumer health information seeking on the Internet: The state of the art. Health Education Research, 16(6), 671-692.

De Meulenaer, S., De Pelsmacker, P. and Dens, N. (2018). Power distance, uncertainty avoidance, and the effects of source credibility on health risk message compliance. Health Communication, 33(3), 291-298.

Dombrowski, S. U., Mackintosh, J. E., Sniehotta, F. F., Araujo-Soares, V., Rodgers, H., Thomson, R. G., ... and White, M. (2013). The impact of the UK 'Act FAST'stroke awareness campaign: Content analysis of patients, witness and primary care clinicians' perceptions. BMC Public Health, 13(1), 1-8.

Evans, W. D., Davis, K. C. and Zhang, Y. (2008). Health communication and marketing research with new media: Case study of the parents speak up national campaign evaluation. Cases in Public Health Communication \& Marketing, 2, 140-158.

Flynn, D., Ford, G. A., Rodgers, H., Price, C., Steen, N. and Thomson, R. G. (2014). A time series evaluation of the FAST national stroke awareness campaign in England. PloS One, 9(8), e104289.

Fogle, C. C., Oser, C. S., Troutman, T. P., McNamara, M., Williamson, A. P., Keller, M., ... and Harwell, T. S. (2008). Public education strategies to increase awareness of stroke warning signs and the need to call 911. Journal of Public Health Management and Practice, 14(3), e17-e22.

Hickey, A., O'Hanlon, A., McGee, H., Donnellan, C., Shelley, E., Horgan, F. and O'Neill, D. (2009). Stroke awareness in the general population: knowledge of stroke risk factors and warning signs in older adults. BMC Geriatrics, 9(1), 1-8. 
$\mathrm{Hu}$, Y. (2015). Health communication research in the digital age: A systematic review. Journal of Communication in Healthcare, 8(4), 260-288.

inme.org.tr (2021). https://www.inme.org.tr/, Erişim Tarihi: 11.02.2021.

Korda, H. and Itani, Z. (2013). Harnessing social media for health promotion and behavior change. Health Promotion Practice, 14(1), 15-23.

Mellon, L., Hickey, A., Doyle, F., Dolan, E. and Williams, D. (2013). Can a media campaign change health service use in a population with stroke symptoms? Examination of the first Irish stroke awareness campaign. Emergency Medicine Journal, 31(7), 536-540.

Mendi, B. (2015). Sağlık iletişiminde sosyal medyanın kullanımı: Dünyadaki ve Türkiye'deki uygulamalar. Öneri Dergisi, 11(44), 275-290.

Milliyet. (2018). https://www.milliyet.com.tr/yerel-haberler/eskisehir/eskisehirde-inmefarkindalik-projesi-13126060, Erişim Tarihi: 19.02.2021.

Moorhead, S. A., Hazlett, D. E., Harrison, L., Carroll, J. K., Irwin, A. and Hoving, C. (2013). A new dimension of health care: Systematic review of the uses, benefits, and limitations of social media for health communication. Journal of Medical Internet Research, 15(4), e85.

Nordanstig, A., Asplund, K., Norrving, B., Wahlgren, N., Wester, P. and Rosengren, L. (2017). Impact of the Swedish National Stroke Campaign on stroke awareness. Acta Neurologica Scandinavica, 136(4), 345-351.

Öztürk, G. ve Öymen, G. (2013). Sağl1k iletişiminde sosyal medya kullanımının stratejik önemi: Türkiye'de kalp sağlı̆̆1 ile ilgili kâr amacı gütmeyen kuruluşlar üzerine bir değerlendirme. Galatasaray Üniversitesi İletişim Dergisi, (Özel Sayı: 3), 109-132.

Rhoads, K. V. and Cialdini, R. B. (2002). The business of influence: Principles that lead to success in commercial settings. Dillard, J. P., and Pfau, M. (Eds.). The persuasion handbook: Developments in theory and practice. (513-542). Thousand Oaks: Sage.

Silver, F. L., Rubini, F., Black, D. and Hodgson, C. S. (2003). Advertising strategies to increase public knowledge of the warning signs of stroke. Stroke, 34(8), 1965-1968.

Şener, E. ve Samur, M. (2013). Sağlığı geliştirici bir unsur olarak sosyal medya: Facebook'ta sağlık. Gümüşhane Üniversitesi Sağlık Bilimleri Dergisi, 2(4), 508523.

Taşkıran, H. B. ve Yıldız, E. (2019). Sağlığa ilişkin risklerin önlenmesi bağlamında sağlık iletişimi kampanyalarının ve yeni medyanın rolü. Dördüncü Kuvvet Uluslararası Hakemli Dergi, 2(2), 111-133.

Taubenheim, A. M., Long, T., Wayman, J., Temple, S., McDonough, S. and Duncan, A. (2012). Using social media to enhance health communication campaigns. S. M. Noar and N. G. Harrington (Eds.) eHealth applications: Promising strategies for behavior change. (205-220). New York: Routledge.

Topçuoğlu, M. A. (2020). Türk beyin damar hastalıkları derneği ve pandemide inmeyi unutmamak. Türk Beyin Damar Hastalıkları Dergisi, 26(2): 150-152.

Tosyal1, H. ve Sütçü, C. S. (2016). Sağlık iletişiminde sosyal medya kullanımının bireyler üzerindeki etkileri. Maltepe Üniversitesi İletişim Fakültesi Dergisi, 3(2), 3-22. 
Willemsen, L. M., Mazerant, K., Kamphuis, A. L. and van der Veen, G. (2018). Let's get real (time)! The potential of real-time marketing to catalyze the sharing of brand messages. International Journal of Advertising, 37(5), 828-848.

Worthmann, H., Schwartz, A., Heidenreich, F., Sindern, E., Lorenz, R., Adams, H. A., ... and Dengler, R. (2013). Educational campaign on stroke in an urban population in Northern Germany: Influence on public stroke awareness and knowledge. International Journal of Stroke, 8(5), 286-292.

Yin, R. K. (2018). Case study research and applications: design and methods. (6th Ed). Los Angeles: Sage Publications.

Yüksel, E. (2018). Sağlık iletişiminin anatomisi. E. Yüksel (Ed.) Akademik bakış-I: Sağlık haberciliği. (s. 11-31). Konya: Literatürk.

Zhao, Y. and Zhang, J. (2017). Consumer health information seeking in social media: A literature review. Health Information \& Libraries Journal, 34(4), 268-283. 